\title{
GMR
}

\section{Effects of feeding conditions on gene expression in chicken breast muscle}

G.L. Gao*, C. Wang*, X.Z. Zhao, H.W. Wang, Q. Li, J. Li, K.S. Zhang, H. Zhong and Q.G. Wang

Chongqing Academy of Animal Sciences, Chongqing, China

*These authors contributed equally to this study.

Corresponding author: Q.G. Wang

E-mail: wangqigui@hotmail.com

Genet. Mol. Res. 16 (1): gmr16019119

Received September 1, 2016

Accepted November 16, 2016

Published January 23, 2017

DOI http://dx.doi.org/10.4238/gmr16019119

Copyright (C) 2017 The Authors. This is an open-access article distributed under the terms of the Creative Commons Attribution ShareAlike (CC BY-SA) 4.0 License.

ABSTRACT. Chicken meat quality is becoming increasingly important
among breeders and consumers. To understand the effect of feeding
conditions on chicken meat quality, we investigated the profiles of
genes expressed in chicken breast muscle. Using RNA sequencing,
we identified 336, 321, and 387 differentially expressed genes among
Chengkou, Daninghe, and Qingjiaoma chickens under scatter- and
captivity-feeding conditions. Twenty-two genes differentially expressed
between different feeding conditions were shown to be common among
the three breeds. Seven of these genes were assessed by real-time
quantitative PCR, which confirmed the findings of RNA sequencing
and suggested that the results were viable. The differentially expressed
genes showed enrichment for a series of significant pathways, including
energy metabolism, xenobiotics biodegradation and metabolism,
and the immune system. These results provide a solid foundation for
elucidating the molecular mechanisms underlying chicken meat quality.

Key words: Chicken; Meat quality; Feeding conditions; Carcass; Genes expression 


\section{INTRODUCTION}

In recent years, the consumption of chicken meat has increased and consumers have started to pay more attention to meat quality (Van Loo et al., 2014; Sans and Combris, 2015; Vorley and Lançon, 2016). The quality of chicken meat is affected by several factors, such as age, breed (Glamoclija et al., 2015), sex, and genotype of the bird (Djilali et al., 2016), as well as diet (Zhai et al., 2016), and feed conditions (HuiFeng et al., 2014). Meat quality can be assessed by a number of indices, including the concentration of inosine 5'-monophosphate (IMP) (Hamano and Kurimoto, 2016), intramuscular fat (IMF) content (Li et al., 2013a), pH, color, drip loss, cooking loss, and cooked meat shear force (Mudalal et al., 2015). Additionally, some customers prefer free-range meat because they believe that it has superior sensory qualities and improved taste (Latter-Dubois, 2001).

Many genes are associated with the quality of chicken meat (Liu et al., 2013), such as the fibroblast growth factor-binding protein (Felício et al., 2013) and fatty acid-binding protein (FABP) gene families (Li et al., 2006), MYBPC1, CETP, GLTPD1, SNX4 (Cui et al., 2012), and MSTN1 genes (Xu et al., 2015). Although many previous studies have investigated chicken meat quality, the mechanisms underlying these quality traits are unknown. We previously showed that IMP and IMF levels in chicken breast muscle differ significantly according to whether the chickens were fed under captivity-feed or scatter-feed conditions (HuiFeng et al., 2014). In the present study, we aimed to evaluate the effect of feeding conditions on gene expression in chicken muscle. To this end, we used high-throughput sequencing to identify the genes expressed in breast muscle from Chengkou (CK), Daninghe (DNH), and Qingjiaoma (QJM) chickens raised under captivity-feed and scatter-feed conditions. We then compared these gene expression profiles.

\section{MATERIAL AND METHODS}

\section{Ethics statement}

This study was approved by the Research Ethics Committee and the Animal Ethical Committee of Chongqing Academy of Animal Sciences. The experiments were performed in accordance with the Laboratory Animal Management Committee of Chongqing Academy of Animal Sciences and the Ministry of Science and Technology of the People's Republic of China (approval No.: 2006-398).

\section{Animals}

A total of $600-800 \mathrm{CK}, \mathrm{DNH}$, and QJM female chickens were reared to the age of 5 months, fed the same diet, and provided water without the addition of antibiotics, growth promoters, hormones, or animal products in Wulong County, Chongqing, China (Table 1) (Gao et al., 2015). Two different feeding conditions were applied: scatter-feed and captivity-feed, which have been previously described (Gao et al., 2015). This gave a total of six groups: CK chickens under scatter-feed conditions (SFCK), CK chickens under captivity-feed conditions (CFCK), DNH chickens under scatter-feed conditions (SFDNH), DNH chickens under captivity-feed conditions (CFDNH), QJM chickens under scatter-feed conditions (SFQJM), and QJM chickens under captivity-feed conditions (CFQJM). We randomly selected five

Genetics and Molecular Research 16 (1): gmr16019119 
female chickens from each group for use as the experimental animals. Breast muscle was collected from each chicken and immediately frozen in liquid nitrogen, then stored at $-80^{\circ} \mathrm{C}$ for further study.

Table 1. Basic diet and nutrient levels.
\begin{tabular}{|c|c|l|c}
\hline Raw material & Content $\%$ & Nutritional index & Nutritional level \\
\hline Corn & 65.00 & Metabolizable energy & 13.39 \\
\hline Soybean meal & 23.00 & Crude protein & 18.00 \\
\hline Cottonseed meal & 3.50 & Lysine & 0.85 \\
\hline Corn gluten meal & 3.00 & Egg + light & 0.60 \\
\hline Grease & 2.00 & Ca/\% & 0.80 \\
\hline Limestone & 1.00 & $\mathrm{P}$ & 0.65 \\
\hline CaHPO & 1.20 & & \\
\hline NaCl & 0.30 & & \\
\hline Premix & 1.00 & & \\
\hline Per inlog
\end{tabular}

Per kilogram premix ingredients: VA $=5000 \mathrm{IU} / \mathrm{kg} ; \mathrm{VD}=31,000 \mathrm{IU} / \mathrm{kg} ; \mathrm{VE}=10 \mathrm{IU} / \mathrm{kg} ; \mathrm{VK}=0.5 \mathrm{IU} / \mathrm{kg}$; pantothenic acid = $10 \mathrm{mg}$; niacin $=30 \mathrm{mg} ; \mathrm{VB} 1=1.8 \mathrm{mg} ; \mathrm{VB} 2=3.5 \mathrm{mg} ; \mathrm{VB} 6=3.5 \mathrm{mg}$; biotin = $0.1 \mathrm{mg}$; folic acid $=0.55 \mathrm{mg}$; choline $=1.0 \mathrm{~g} ; \mathrm{VB} 12=0.012 \mathrm{mg} ; \mathrm{Mn}=80 \mathrm{mg} ; \mathrm{Zn}=60 \mathrm{mg} ; \mathrm{Fe}=80 \mathrm{mg} ; \mathrm{Cu}=8 \mathrm{mg} ;$ and $\mathrm{Se}=0.15 \mathrm{mg}$.

\section{RNA sequencing and genomic annotation}

Total RNA was isolated from chicken breast muscle using Trizol reagent (15596-026; Invitrogen, Carlsbad, CA, USA). Isolated RNA was quantified by spectrophotometry and its integrity checked using 1\% agarose gel electrophoresis to confirm that it was suitable for constructing cDNA libraries and for use in quantitative real-time PCR analysis. Total mRNA was purified using oligo (dT) magnetic beads, and cleaved into fragments (approximately $155 \mathrm{bp})$. Samples of total RNA from each group (5 x $2 \mathrm{mg}$ ) were pooled to construct cDNA libraries, which were sequenced using the Illumina HiSeq platform (Shanghai Personal Biotechnology Co., Ltd., Shanghai, China).

Clean reads were generated from raw data after removing adaptors, reads with uncertain base calls, low-quality bases, or reads shorter than $50 \mathrm{bp}$. Reads were then mapped and annotated against the chicken genome using the Bowtie2/TopHat2 software (Trapnell et al., 2009). We performed homology searches against Ensembl and searched for evolutionary genealogy using Non-supervised Orthologous Group (eggNOG) databases (Tatusov et al., 2003; Powell et al., 2012). We also predicted metabolic pathways and gene ontology of reads using the Kyoto Encyclopedia of Genes and Genomes (KEGG) and the Gene Ontology (GO) websites, respectively. Reads per kilobase of exon model per million mapped reads were used to normalize read abundance (Mortazavi et al., 2008). RNA-seq databases generated from SFDNH, CFDNH, SFQJM, and CFQJM in this study were used to analyze genes that were affected by feeding conditions but not by breed, as shown in our previous study (Gao et al., 2015). In the present study, we integrated SFCK and CFCK chicken RNA-seq databases with the four previously published databases to analyze genes affected by feeding conditions (Gao et al., 2015).

\section{Quantitative real-time PCR}

The expression of seven genes that were differentially expressed in all three breeds (HSP7, FOXO3, L-FABP, MUSTN1, CSRP 3, ASNS, and MX) was measured by quantitative real-time PCR (qRT-PCR). Optimal primers for the amplification of these genes were designed 
using the NCBI website and synthesized by Invitrogen Biotechnology (Table 2). The chicken glyceraldehyde-3-phosphate dehydrogenase $(G A P D H)$ gene was selected as an internal control. qRT-PCR was performed using the ROX Reference Dye II kit (TaKaRa, Dalian, China) with the 7900HT Sequence Detection System (Applied Biosystems, Foster City, CA, USA).

Table 2. Primer sequences used for qRT-PCR.

\begin{tabular}{|c|c|c|c|c|}
\hline Symbol & Gene name & GenBank accession No. & Primer & Amplicon size (bp) \\
\hline \multirow[t]{2}{*}{ HSP70 } & \multirow[t]{2}{*}{ Heat shock $70 \mathrm{kDa}$ protein } & \multirow[t]{2}{*}{ AY178443.1 } & F: 5'- GCGAGTGGCTGACTGACCA-3' & \multirow[t]{2}{*}{230} \\
\hline & & & R: 5'-AAGTATGATGACCCCACA -3' & \\
\hline \multirow[t]{2}{*}{ FOXO3 } & \multirow[t]{2}{*}{ Forkhead box $\mathrm{O} 3$} & \multirow[t]{2}{*}{ HGNC:3821 } & F: 5'-CGTTGTCAGTCTGAATGTGGGG-3' & \multirow[t]{2}{*}{122} \\
\hline & & & R: 5'-GACAGCAGATTTGGCAAAGGG-3' & \\
\hline \multirow[t]{2}{*}{$L-F A B P$} & \multirow[t]{2}{*}{ Fatty acid-binding protein, liver } & \multirow[t]{2}{*}{ NP_989523 } & F: 5'-GCAGAATGGGAATAAGTT-3' & \multirow[t]{2}{*}{212} \\
\hline & & & R: 5'-TTGTATGGGTGATGGTGT-3' & \\
\hline \multirow[t]{2}{*}{ MUSTNI } & \multirow[t]{2}{*}{ Musculoskeletal embryonic nuclear protein 1} & \multirow[t]{2}{*}{ Q76MS9 } & F: 5'-TGAAGGAGGAAGATCTCAAAGGA-3' & \multirow[t]{2}{*}{98} \\
\hline & & & R: 5'-GCCCATTTGTTCACACTGCTT-3' & \\
\hline \multirow[t]{2}{*}{ CSRP3 } & \multirow[t]{2}{*}{ Cysteine and glycine-rich protein 3} & \multirow[t]{2}{*}{ NM_001199486 } & F: 5'-CTGTGGCAAATCGGTGTA-3' & \multirow[t]{2}{*}{130} \\
\hline & & & R: 5'-CTCTCCGTCTTTGTCTGTAAC-3' & \\
\hline \multirow[t]{2}{*}{$A S N S$} & \multirow[t]{2}{*}{ Asparagine synthetase } & \multirow[t]{2}{*}{ NM_001030977 } & F: 5'-GCAGAAGAGAGCGAGAGG-3' & \multirow[t]{2}{*}{112} \\
\hline & & & R: 5'-GATGATCCAAAAACGGGA-3' & \\
\hline \multirow[t]{2}{*}{$M X$} & \multirow[t]{2}{*}{ Interferon-induced GTP-binding protein Mx } & \multirow[t]{2}{*}{ AY695797 } & F: 5'-AAATGGCTCAAGAGGTGGA-3' & \multirow[t]{2}{*}{207} \\
\hline & & & R: 5'-CTTGCTGGATTGTGGAGGT-3' & \\
\hline \multirow[t]{2}{*}{ GAPDH } & \multirow[t]{2}{*}{ Glyceraldehyde-3-phosphate dehydrogenase } & \multirow[t]{2}{*}{ NM_204305.1 } & F: 5'-GTGGTGCTAAGCGTGTCA-3' & \multirow[t]{2}{*}{182} \\
\hline & & & R: 5'-GGCTGGGATAATGTTCTGG-3' & \\
\hline
\end{tabular}

\section{Statistical analyses}

We used a fold-change of $>2$ and $\mathrm{P}<0.05$ as criteria to identify differentially expressed genes (DEGs) in pairwise comparisons among the groups. The expression of each gene relative to GAPDH was calculated by the $2^{-\Delta \Delta C t}$ method (Livak and Schmittgen, 2001).

\section{RESULTS}

\section{Gene expression analysis}

The effects of feeding conditions on candidate genes for meat quality were assessed using the Illumina HiSeq 2000 platform $(2 \times 100 \mathrm{bp})$. In total, 13,349,711,000 raw data and $66,748,555$ raw reads were obtained from six libraries (SFCK, SFDNH, SFQJM, CFCK, CFDNH, and CFQJM). After trimming and quality checking, 59,211,097 clean reads were recorded with 11,513,047,868 clean reads from the six groups (Table 3). There were 15,508 genes expressed in the six groups. More than $86 \%$ of the data were useful, and the raw data were filtered by Q20 or Q30 to more than 96 or $90 \%$, respectively, which suggested that the results were reliable.

\section{Differential gene expression analysis}

We found that 336,321 , and 387 genes were differentially expressed between the SFCK and CFCK (Table S1), SFDNH and CFDNH (Table S2), and SFQJM and CFQJM groups, respectively (Table $\mathbf{S 3}$ ). Of these, 22 genes were common to all three pairwise comparisons, suggesting that their expression was affected by the feeding conditions (Figure 1 and Table S4). Seven of the 22 genes have been investigated in previous studies, and their structures are available on the NCBI website. However, the other genes were labeled as "uncharacterized 
protein" or "transcript" (Table S4 $)$, and the intron/exon structures, and sequences of these genes were unknown, which made it difficult to design PCR primers. Therefore, we selected the abovementioned seven genes for qRT-PCR analysis to confirm the RNA sequencing findings (Figure 2). The results were consistent with those obtained by RNA sequencing, indicating that this technique is reliable.

Table 3. Sequencing and mapping of cDNA libraries from chicken breast muscle.

\begin{tabular}{l|c|c|c|c|c|c|c}
\hline & SYCK & SYDNH & SYRZ & LYCK & LYDNH & LYRZ & Total \\
\hline Useful data (\%) & $86.02 \%$ & $86.17 \%$ & $86.77 \%$ & $86.02 \%$ & $86.50 \%$ & $85.92 \%$ & \\
\hline Q20 (\%) & $96.54 \%$ & $96.50 \%$ & $96.67 \%$ & $96.51 \%$ & $96.60 \%$ & $96.39 \%$ & \\
\hline Q30 (\%) & $90.30 \%$ & $90.13 \%$ & $90.59 \%$ & $90.21 \%$ & $90.56 \%$ & $90.17 \%$ & \\
\hline Useful reads & $21,124,372$ & $19,649,360$ & $20,905,912$ & $18,386,148$ & $19,468,504$ & $18,887,898$ & \\
\hline Mapped percent (\%) & $84.33 \%$ & $85.82 \%$ & $86.67 \%$ & $85.99 \%$ & $86.49 \%$ & $87.02 \%$ & \\
\hline Raw data (bp) & $2,376,298,400$ & $2,217,737,400$ & $2,345,482,800$ & $2,076,351,400$ & $2,192,732,200$ & $2,141,108,800$ & $13,349,711,000$ \\
\hline Raw reads & $11,881,492$ & $11,088,687$ & $11,727,414$ & $10,381,757$ & $10,963,661$ & $10,705,544$ & $66,748,555$ \\
\hline Clean data (bp) & $2,044,167,938$ & $1,911,115,133$ & $2,035,140,809$ & $1,786,150,261$ & $1,896,738,173$ & $1,839,735,554$ & $11,513,047,868$ \\
\hline Clean reads & $10,562,186$ & $9,824,680$ & $10,452,956$ & $9,193,074$ & $9,734,252$ & $9,443,949$ & $59,211,097$ \\
\hline
\end{tabular}

SFCK $=$ CK chickens under scatter-feed conditions; $\mathrm{CFCK}=\mathrm{CK}$ chickens under captivity-feed conditions; $\mathrm{SFDNH}$ $=\mathrm{DNH}$ chickens under scatter-feed conditions; $\mathrm{CFDNH}=\mathrm{DNH}$ chickens under captivity-feed conditions; SFQJM

$=\mathrm{QJM}$ chickens under scatter-feed conditions; CFQJM = QJM chickens under captivity-feed conditions.

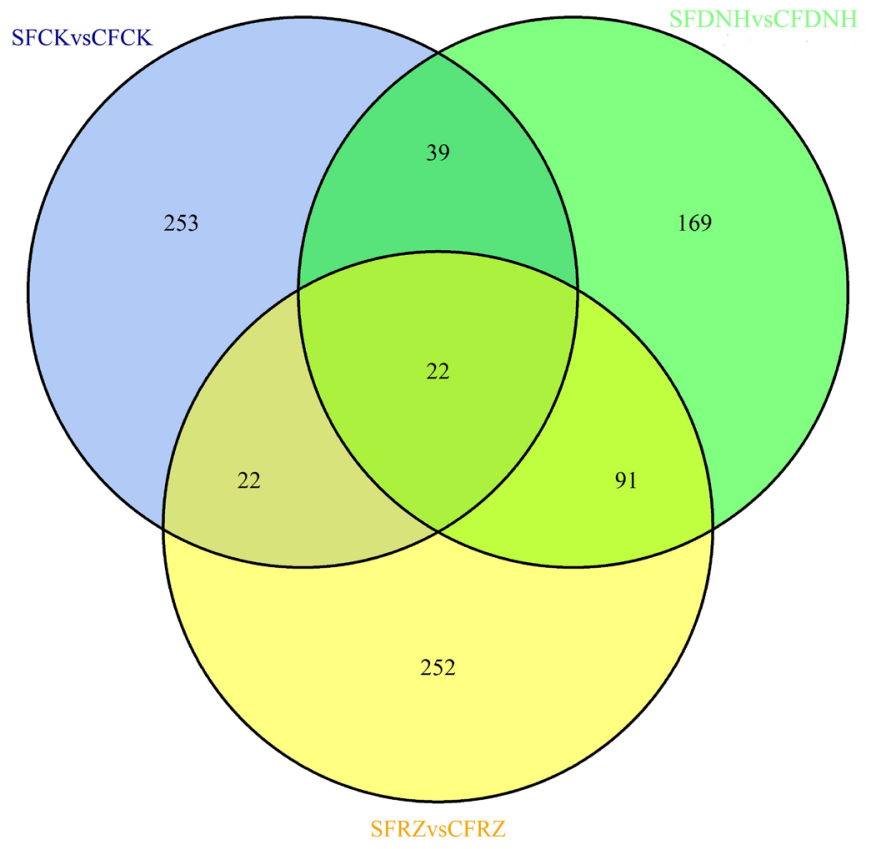

Figure 1. Summary of genes differentially expressed in chicken breast muscle. SFCK $=$ Chengkou chickens raised under scatter-feed conditions; SFDNH = Daninghe chickens raised under scatter-feed conditions; SFQJM = Qingjiaoma chickens raised under scatter-feed conditions; $\mathrm{CFCK}=$ Chengkou chickens raised under captivity-feed conditions; $\mathrm{CFDNH}=\mathrm{DNH}$ chickens raised under captivity-feed conditions; $\mathrm{CFQJM}=\mathrm{QJM}$ chickens raised under captivity-feed conditions.

Genetics and Molecular Research 16 (1): gmr16019119 

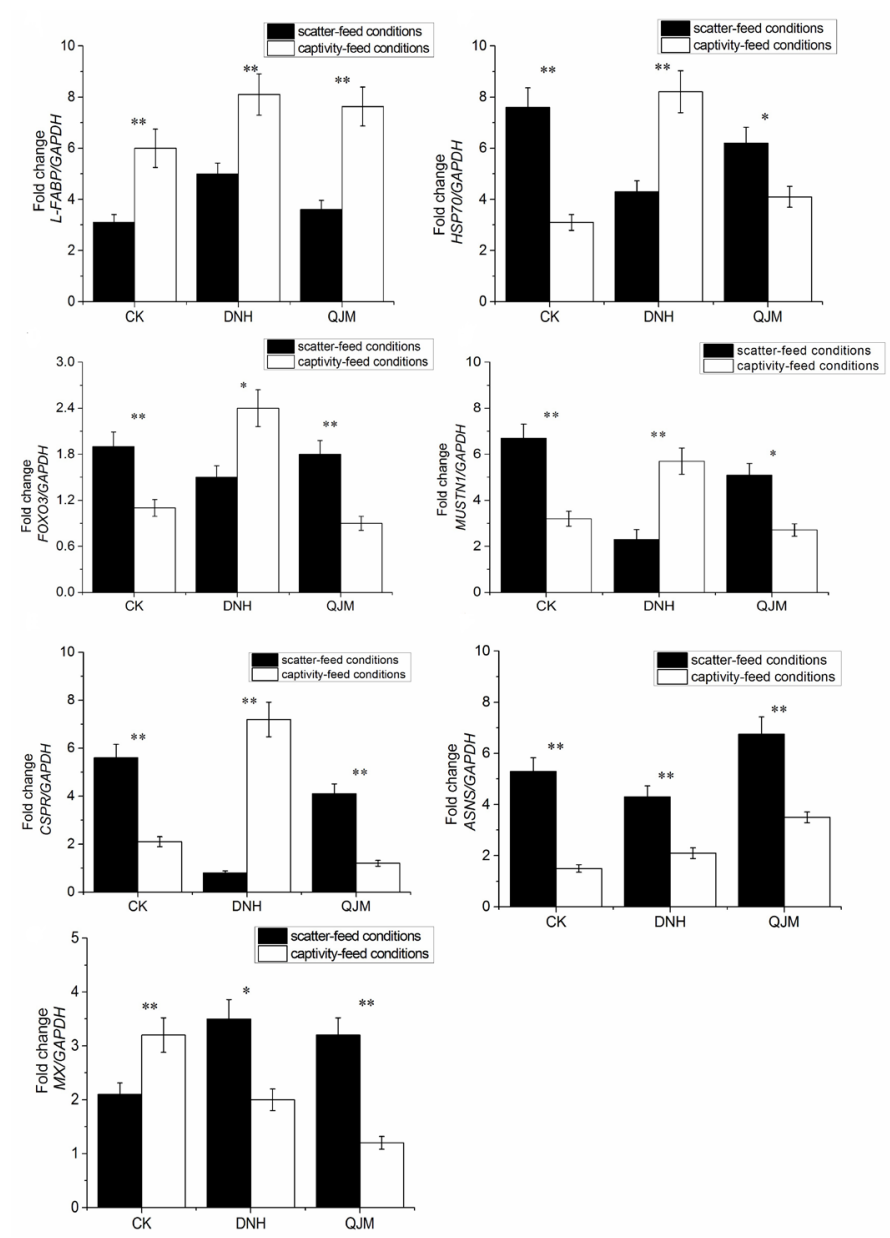

Figure 2. Real-time PCR validation of differentially expressed genes (DEGs) obtained from RNA-seq. **Highly significant at $\mathrm{P} \leq 0.01 ; *$ significantly different at $\mathrm{P} \leq 0.05$.

FOXO3 is involved in many cellular activities, such as DNA damage repair, apoptosis, response to oxidative stress, cell growth and differentiation, cell cycle control, and energy metabolism (Medema et al., 2000; Kops et al., 2002; Tran et al., 2002; Sanchez et al., 2014). Previous studies have shown that $\mathrm{FOXO3}$ plays a crucial role in skeletal muscle development, and in the inhibition of proliferation and differentiation in duck myoblast skeletal muscle (Gan et al., 2016). This gene is also differentially expressed in chicken muscles with different glycogen contents, indicating that it could be involved in glycogen metabolism in chicken muscle (Sibut et al., 2011). The glycogen content in breast muscle was previously found to be related to growth rate and breast meat yield (Berri et al., 2001; Berri et al., 2007), as well as carcass fatness (Le BihanDuval et al., 2001; Sibut et al., 2008). Consistent with these findings, and with our earlier work in chickens (HuiFeng et al., 2014), we also showed that FOXO3 mRNA expression differs according to the feed condition (Figure 2). We can infer from this that the feeding conditions affected the expression of $\mathrm{FOXO3}$, leading to changes in glycogen metabolism in chicken muscle. 
Musculoskeletal embryonic nuclear protein 1 (encoded by MUSTN1) regulates muscle development and growth in chickens ( $\mathrm{Li}$ et al., 2012; Li et al., 2013b) and is involved in bone regeneration (Hadjiargyrou et al., 2002), myogenesis, cell differentiation, and muscle fiber fusion (Liu et al., 2010). The amino acid sequence of MUSTN1 is evolutionarily conserved between birds and mammals, and MUSTN1 may play an important role in breast muscle development in ducks (Xu et al., 2015). We observed the differential expression of MUSTN1 under different feed conditions, suggesting that they affect MUSTN1 expression and the process of muscle development.

\section{GO categorization and KEGG terms analysis}

For all three pairwise groups, the DEGs were classified into functional GO categories and KEGG terms. Functional analysis revealed that 86, 87, and $91 \mathrm{GO}$ categories, and 31, 29, and 30 KEGG terms were mapped for the SFCK versus CFCK, SFRZ versus CFRZ, and SFDNH versus CFDNH comparisons, respectively. The top 10 significantly different GO categories and KEGG terms of the DEGs are shown in Figure 3.

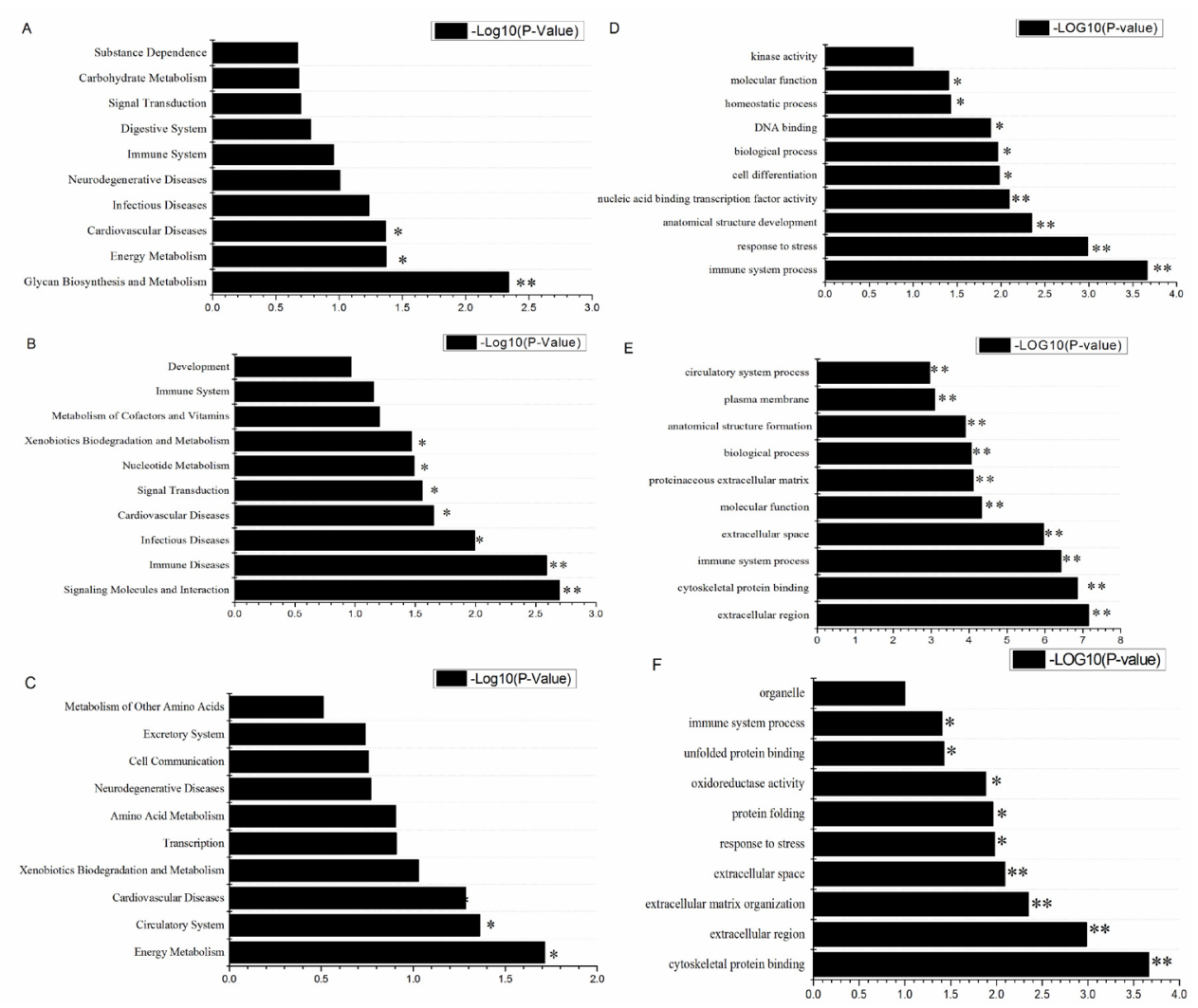

Figure 3. Top 10 KEGG (Kyoto Encyclopedia of Genes and Genomes) and GO (Gene Ontology) terms of the DEGs in chicken breast muscle. A. KEGG terms of SFRZ versus CFRZ; B. KEGG terms of SFCK versus CFCK; C. KEGG terms of SFDNH versus SFQJM; D. GO terms of SFRZ versus CFRZ; E. GO terms of SFCK versus CFCK; F. GO terms of SFDNH versus SFQJM. **Highly significant at $\mathrm{P} \leq 0.01$; * significantly different at $\mathrm{P} \leq 0.05$. 
Energy metabolism, xenobiotic biodegradation and metabolism, and immune system pathways showed significant differences among all three pairwise comparisons, suggesting that they are affected by feed conditions. Similarly, the GO terms, response to stress, immune system process, and extracellular regions were significantly different in all three comparisons, also suggesting that they are affected by feed conditions.

\section{DISCUSSION}

In this study, next-generation sequencing technology was used to identify genes that are differentially expressed between CK, QJM, and DNH chickens reared under scatter-feed or captivity-feed conditions. Seven meat quality-related candidate genes ( $L-F A B P, H S P 70$, FOXO3, MUSTN1, CSRP3, ASNS, and MX) were found to be differentially expressed in chicken breast muscle between the two feeding conditions, suggesting that they are important candidate genes of chicken meat quality. QJM is a broiler breed of chicken, while DNH and $\mathrm{CK}$ are local chicken breeds raised for both meat and eggs. The meat quality (IMP and IMF) of QJM chickens is significantly different from that of DNH and CK chickens (HuiFeng et al., 2014). In the present study, we found the trend of expression of some genes (HSP70, FOXO3, MSUSTN1, and CBPR) to be different in QJM chickens from in the other two groups (Figure 2 ). We suspect that these differences are associated with the special QJM breed of chicken.

mRNA levels do not always correlate with protein levels (Gygi et al., 1999) because complicated post-transcriptional regulation can occur (Blackinton and Keene, 2014). Therefore, RT-PCR analysis is limited in its ability to identify markers and mediators of cellular processes without additional tests.

According to our DEG annotations, several GO categorizations and KEGG terms differ significantly in response to feeding conditions, such as the immune system and response to stress. This study lays the foundation for elucidating the molecular mechanisms underlying chicken meat quality.

\section{Conflicts of interest}

The authors declare no conflicts of interest.

\section{ACKNOWLEDGMENTS}

Research supported by Chongqing Social Livelihood Scientific and Technological Innovation projects (\#cstc2016shmszx80034), the Chongqing Agricultural Development Foundation (\#16404) and Chongqing Fundamental Research Funds projects (\#14405).

\section{REFERENCES}

Berri C, Wacrenier N, Millet N and Le Bihan-Duval E (2001). Effect of selection for improved body composition on muscle and meat characteristics of broilers from experimental and commercial lines. Poult. Sci. 80: 833-838. http:// dx.doi.org $/ 10.1093 / \mathrm{ps} / 80.7 .833$

Berri C, Le Bihan-Duval E, Debut M, Santé-Lhoutellier V, et al. (2007). Consequence of muscle hypertrophy on characteristics of Pectoralis major muscle and breast meat quality of broiler chickens. J. Anim. Sci. 85: 2005-2011. http://dx.doi.org/10.2527/jas.2006-398

Blackinton JG and Keene JD (2014). Post-transcriptional RNA regulons affecting cell cycle and proliferation. Semin. Cell Dev. Biol. 34: 44-54. http://dx.doi.org/10.1016/j.semcdb.2014.05.014

Genetics and Molecular Research 16 (1): gmr16019119 
Cui HX, Liu RR, Zhao GP, Zheng MQ, et al. (2012). Identification of differentially expressed genes and pathways for intramuscular fat deposition in pectoralis major tissues of fast-and slow-growing chickens. BMC Genomics 13: 213. http://dx.doi.org/10.1186/1471-2164-13-213

Djilali B, Benmehel B, Farouk B and Miloud H (2016). Effects of genotype and sex on lipid oxidation and fatty acid profile of chicken breast meat. Pak. J. Nutr. 15: 187. http://dx.doi.org/10.3923/pjn.2016.187.193

Felício AM, Boschiero C, Balieiro JC, Ledur MC, et al. (2013). Polymorphisms in FGFBP1 and FGFBP2 genes associated with carcass and meat quality traits in chickens. Genet. Mol. Res. 12: 208-222. http://dx.doi.org/10.4238/2013. $\underline{\text { January. } 24.13}$

Gan W, He H and Li L (2016). Molecular cloning, characterisation and functional analysis of the duck Forkhead box O3 (FOXO3) gene. Br. Poult. Sci. 57: 143-150. http://dx.doi.org/10.1080/00071668.2015.1135503

Gao GL, Wang HW, Zhao XZ, Li Q, et al. (2015). Feeding conditions and breed affect the level of DNA methylation of the mitochondrial uncoupling protein 3 gene in chicken breast muscle. J. Anim. Sci. 93: 1522-1534. http://dx.doi. org $/ 10.2527 / j a s .2014-8431$

Glamoclija N, Starcevic M, Janjic J, Ivanovic J, et al. (2015). The effect of breed line and age on measurements of pHvalue as meat quality parameter in breast muscles (m. pectoralis major) of broiler chickens. Procedia Food Sci. 5: 89-92. http://dx.doi.org/10.1016/j.profoo.2015.09.023

Gygi SP, Rochon Y, Franza BR and Aebersold R (1999). Correlation between protein and mRNA abundance in yeast. Mol. Cell. Biol. 19: 1720-1730. http://dx.doi.org/10.1128/MCB.19.3.1720

Hadjiargyrou M, Lombardo F, Zhao S, Ahrens W, et al. (2002). Transcriptional profiling of bone regeneration. Insight into the molecular complexity of wound repair. J. Biol. Chem. 277: 30177-30182. http://dx.doi.org/10.1074/jbc. M203171200

Hamano Y and Kurimoto Y (2016). Effects of acetylated wood powder on growth performance, hepatic and muscular free amino acid profiles, and inosine 5'-monophosphate concentration of breast meat in broiler chickens. Br. Poult. Sci. 57: 643-654.

HuiFeng Z, GuangLiang G, HaiWei W, YouHui X, et al. (2014). Effects of different breeds and raising modes on meat flavors and candidate genes expression levels. J. Agric. Biotechnol. 22: 1018-1026.

Kops GJ, Dansen TB, Polderman PE, Saarloos I, et al. (2002). Forkhead transcription factor FOXO3a protects quiescent cells from oxidative stress. Nature 419: 316-321. http://dx.doi.org/10.1038/nature01036

Latter-Dubois J (2001). Poulets fermiers: leurs qualités nutritionnelles et organoleptiques et la perception du consommateur. Master's thesis, Université Laval, Quebec, Canada.

Le Bihan-Duval E, Berri C, Baeza E, Millet N, et al. (2001). Estimation of the genetic parameters of meat characteristics and of their genetic correlations with growth and body composition in an experimental broiler line. Poult. Sci. 80: 839-843. http://dx.doi.org/10.1093/ps/80.7.839

Li DL, Chen JL, Wen J, Zhao GP, et al. (2013a). Growth, carcase and meat traits and gene expression in chickens divergently selected for intramuscular fat content. Br. Poult. Sci. 54: 183-189. http://dx.doi.org/10.1080/00071668.2013.771392

Li J, Wang C, Kong F-L, Wang Y, et al. (2012). Association study between the single nucleotide polymorphisms of MUSTN1 gene and carcass traits in chickens. Asian J. Anim. Vet. Adv. 7: 1157-1165. http://dx.doi.org/10.3923/ ajava.2012.1157.1165

Li J, Chen Y, Wang Y-G, Zhao X-L, et al. (2013b). MUSTN1 mRNA abundance and protein localization is greatest in muscle tissues of Chinese meat-quality chickens. Int. J. Mol. Sci. 14: 5545-5559. http://dx.doi.org/10.3390/ ijms14035545

Li WJ, Li HB, Wen J, Chen JL, et al. (2006). Association of the H-FABP and A-FABP gene expression with intramuscular fat content in chickens. Acta Vet. Zootech. Sin 37: 417.

Liu C, Gersch RP, Hawke TJ and Hadjiargyrou M (2010). Silencing of Mustn1 inhibits myogenic fusion and differentiation. Am. J. Physiol. Cell Physiol. 298: C1100-C1108. http://dx.doi.org/10.1152/ajpcell.00553.2009

Liu R, Sun Y, Zhao G, Wang F, et al. (2013). Genome-wide association study identifies Loci and candidate genes for body composition and meat quality traits in Beijing-You chickens. PLoS One 8: e61172. http://dx.doi.org/10.1371/journal. pone. 0061172

Livak KJ and Schmittgen TD (2001). Analysis of relative gene expression data using real-time quantitative PCR and the 2(-Delta Delta C(T)) Method. Methods 25: 402-408. http://dx.doi.org/10.1006/meth.2001.1262

Medema RH, Kops GJ, Bos JL and Burgering BM (2000). AFX-like Forkhead transcription factors mediate cell-cycle regulation by Ras and PKB through p27kip1. Nature 404: 782-787. http://dx.doi.org/10.1038/35008115

Mortazavi A, Williams BA, McCue K, Schaeffer L, et al. (2008). Mapping and quantifying mammalian transcriptomes by RNA-Seq. Nat. Methods 5: 621-628. http://dx.doi.org/10.1038/nmeth.1226

Mudalal S, Lorenzi M, Soglia F, Cavani C, et al. (2015). Implications of white striping and wooden breast abnormalities on

Genetics and Molecular Research 16 (1): gmr16019119 
quality traits of raw and marinated chicken meat. Animal 9: 728-734. http://dx.doi.org/10.1017/S175173111400295X

Powell S, Szklarczyk D, Trachana K, Roth A, et al. (2012). eggNOG v3.0: orthologous groups covering 1133 organisms at 41 different taxonomic ranges. Nucleic Acids Res. 40: D284-D289. http://dx.doi.org/10.1093/nar/gkr1060

Sanchez AM, Candau RB and Bernardi H (2014). FoxO transcription factors: their roles in the maintenance of skeletal muscle homeostasis. Cell. Mol. Life Sci. 71: 1657-1671. http://dx.doi.org/10.1007/s00018-013-1513-z

Sans P and Combris P (2015). World meat consumption patterns: An overview of the last fifty years (1961-2011). Meat Sci. 109: 106-111. http://dx.doi.org/10.1016/j.meatsci.2015.05.012

Sibut V, Le Bihan-Duval E, Tesseraud S, Godet E, et al. (2008). Adenosine monophosphate-activated protein kinase involved in variations of muscle glycogen and breast meat quality between lean and fat chickens. J. Anim. Sci. 86: 2888-2896. http://dx.doi.org/10.2527/jas.2008-1062

Sibut V, Hennequet-Antier C, Le Bihan-Duval E, Marthey S, et al. (2011). Identification of differentially expressed genes in chickens differing in muscle glycogen content and meat quality. BMC Genomics 12: 112. http://dx.doi. org/10.1186/1471-2164-12-112

Tatusov RL, Fedorova ND, Jackson JD, Jacobs AR, et al. (2003). The COG database: an updated version includes eukaryotes. BMC Bioinformatics 4: 41. http://dx.doi.org/10.1186/1471-2105-4-41

Tran H, Brunet A, Grenier JM, Datta SR, et al. (2002). DNA repair pathway stimulated by the forkhead transcription factor FOXO3a through the Gadd45 protein. Science 296: 530-534. http://dx.doi.org/10.1126/science.1068712

Trapnell C, Pachter L and Salzberg SL (2009). TopHat: discovering splice junctions with RNA-Seq. Bioinformatics 25: 1105-1111. http://dx.doi.org/10.1093/bioinformatics/btp120

Van Loo EJ, Caputo V, Nayga RM and Verbeke W (2014). Consumers' valuation of sustainability labels on meat. Food Policy 49: 137-150. http://dx.doi.org/10.1016/j.foodpol.2014.07.002

Vorley B and Lançon F (2016). Food consumption, urbanisation and rural transformation. IIED Working Paper.

Xu TS, Gu LH, Sun Y, Zhang XH, et al. (2015). Characterization of MUSTN1 gene and its relationship with skeletal muscle development at postnatal stages in Pekin ducks. Genet. Mol. Res. 14: 4448-4460. http://dx.doi.org/10.4238/2015. May. 4.2

Zhai W, Schilling M, Jackson V, Peebles E, et al. (2016). Effects of dietary lysine and methionine supplementation on Ross 708 male broilers from 21 to 42 days of age (II): breast meat quality. J. Appl. Poult. Res. 25: 212-222. http://dx.doi. org/10.3382/japr/pfw003

\section{Supplementary material}

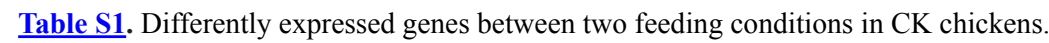

Table S2. Differently expressed genes between two feeding conditions in Daninghe chickens.

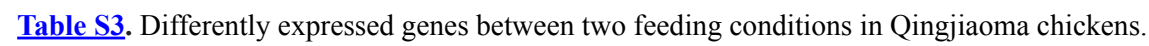

Table S4. Common differently expressed genes between two feeding conditions in CK, Daninghe and Qingjiaoma chickens.

Genetics and Molecular Research 16 (1): gmr16019119 